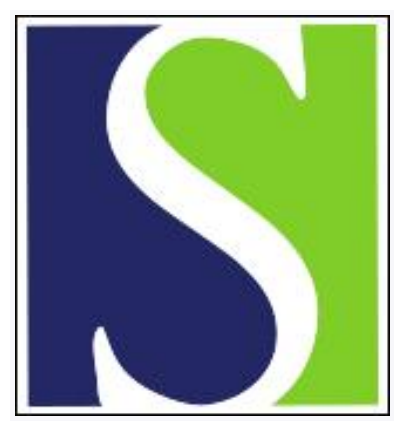

Scand J Work Environ Health 1975;1(1):50-53

https://doi.org/10.5271/sjweh.2860

Issue date: Mar 1975

Biochemical changes caused by asbestos dust in the lungs of rats.

by Rahman Q, Viswanathan PN, Zaidi SH

Key terms: asbestos; asbestos dust; biochemical change; biochemistry; enzyme activity; experimental pneumoconiosis; lung; rat

This article in PubMed: www.ncbi.nlm.nih.gov/pubmed/1235858

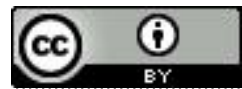




\title{
Biochemical changes caused by asbestos dust in the lungs of rats
}

\author{
by QAMAR RAFMAN, Ph.D., M.U. BEG, Ph.D., P.N. VISWANATHAN, Ph.D., \\ and S.H. ZAIDI, Ph.D. ${ }^{1}$
}

\begin{abstract}
RAHMAN, Q., BEG, M.U., VISWANATHAN, P.N. and ZAIDI, S.H. Biochemical changes caused by asbestos dust in the lungs of rats. Scand. $j$. work environ. \& health 1 (1975) 50--53. The contents of collagen, hexosamine, phospholipids, and cholesterol and the activities of acid and allaline phosphatases, glutamic oxalow acetate transaminase, glutamic pyruvate transminase, aldolase, hexokinase, and lactic dehydrogenase were determined in the lungs of rats 150 days after the intratracheal injection of amosite, anthophyllite, and chrysotile. Anthophyllite did not cause any significant change, while amosite and chrysotile caused significant increases in the contents of collagen and mucopolysaccharides. Lactic dehydrogenase and acid phosphatase activities were increased by all the dusts, while the other enzymes were not seriously affected. The biochemical significance of the findings in relation to asbestosis was discussed.

Key words: experimental pneumoconiosis, asbestos, enzyme activity, biochemical changes, lungs.
\end{abstract}

The biochemical aspects of experimental asbestosis are being studied in this laboratory, especially in relation to the solubility of the dusts under physiological conditions $(8,9,13,15)$. Lysosomal and mitochondrial enzymes have already been found among the targets of the toxic effect of asbestos $(2,14)$. It was of further interest to study the effect of asbestos dust in vivo on soluble enzymes and some tissue constituents of rat lungs, since this aspect has not received sufficient attention. The findings are reported below.

\section{MATERIAL AND MENHODS}

\section{Dusts}

Amosite, anthophylitite, and chrysotile dust samples with a fiber size below $30 \mu$ were prepared according to the procedure

\footnotetext{
1 Industrial Toxicology Research Centre, Lucknow, India.
}

Reprint request to: Dr. Qamar Rahman, Industrial Toxicology Research Centre, Post Box No. 80, Lucknow-226001, India. described by Zaidi (17). The data for the fiber size distribution are recorded in table 1.

\section{Experimental production of asbestosis}

The dust was suspended in physiological saline to give a $0.5 \%(\mathrm{w} / \mathrm{v})$ suspension and was autoclaved at a pressure of $15 \mathrm{lb}$ for 20 minutes. For each dust 10 male albino rats, weighing from 150 to $200 \mathrm{~g}$, from an I.T.R.C. animal colony were intratracheally injected with a single dose of $1.0 \mathrm{ml}$ of the sterilized suspension. The control animals received only saline. The animals were maintained on a laboratory stock diet (18) and were sacrified by dem sanguination after 150 days.

\section{Estimation of chemical constituents}

For chemical analysis a weighed portion of lung was dried at $100^{\circ} \mathrm{C}$ to a constant weight and powdered. Fifty milligrams of the dry powder was used for collagen estimation according to the method of 
Table 1. Percentage of different fiber lengths in the asbestos dust samples.

\begin{tabular}{cccc}
$\begin{array}{c}\text { Fiber } \\
\text { length } \\
\mu\end{array}$ & $\begin{array}{c}\text { Amosite } \\
\%\end{array}$ & $\begin{array}{c}\text { Anthophyllite } \\
\%\end{array}$ & $\begin{array}{c}\text { Chrysotile } \\
\%\end{array}$ \\
\hline$<3$ & 21.3 & 23.3 & 13.4 \\
$3-5$ & 30.0 & 34.9 & 15.7 \\
$6-12$ & 30.3 & 25.7 & 20.6 \\
$13-17$ & 6.1 & 6.6 & 13.9 \\
$18-24$ & 7.9 & 5.5 & 16.8 \\
$25-29$ & 4.3 & 4.1 & 19.5 \\
\hline
\end{tabular}

Stegemann (12) after extraction with benzene. Phospholipids and free and bound cholesterol were estimated by the procedures described by Wootton (16). Mucopolysaccharides were estimated as glycosamine according to Ashwell (1).

\section{Enzyme assay}

Another weighed portion of lung tissue was cut into small pieces and homogenized in ice cold $0.25 \mathrm{M}$ sucrose solution in a Potter-Elvehjem glass homogenizer. Enzyme assays were carried out in the supernatant after removing the mitochondrial fraction by differential centrifugation (10). Hexokinase (E.C. 2.7.1.1), aldolase (E.C. 4.1.2.13), and lactic dehydrogenase (E.C. 1.1.1.27) were assayed by the procedures of Crane and Sols (4), Sibley and Lehninger (11), and Kornberg (5), respectively. The activities of glutamic oxaloacetate transaminase (E.C. 2.6.1.1), glutamic pyru- vate transaminase (E.C. 2.6.1.2), alkaline phosphatase (E.C. 3.1.3.1), and acid phosphatase (E.C. 3.1.3.2) were determined according to Wootton (16). Total protein. was determined, after precipitation with trichloroacetic acid, according to Lowry et al. (7).

\section{RESULTS}

\section{Chemical constituents}

The data for the contents of various chemical constituents in the asbestotic and control lungs are recorded in table 2 .

Amosite. Amosite caused an increase in fresh weight $(83 \%)$, dry solid content $(44 \%)$, and protein content $(35 \%)$. These changes were statistically significant $(p<$ $0.1 \%$, tutest). Collagen content per whole lung showed a $58 \%(p<0.1 \%)$ increase. Similarly expressed in terms of fresh weight, there was also a $41 \%$ increase. Hexosamine content indicated a $71 \%$ increase in terms of fresh weight $(p<1 \%)$. Phospholipid, total cholesterol, and free cholesterol contents did not show any sigm nificant change.

Anthophyllite. The fresh weight of lungs, dry solids, and protein did not show any change in the animals treated with anthophyllite as compared to the controls. Similarly the variations in collagen, hexosamine, phospholipid, and cholesterol were not statistically significant.

Table 2. The mean \pm the standard deviation of six determinations of the gross chemical changes in asbestotic rat lungs.

\begin{tabular}{lcccc}
\hline & Control & Amosite & Anthophyllite & Chrysotile \\
\hline Animal weight a & $180 \pm 25$ & $175 \pm 24$ & $187 \pm 49$ & $172 \pm 35$ \\
Fresh weight of whole lung b & $1.27 \pm 0.28$ & $2.33 \pm 0.68$ & $1.27 \pm 0.33$ & $3.42 \pm 1.5$ \\
Dry solids $b$ & $182 \pm 10.5$ & $242 \pm 42$ & $204 \pm 9.7$ & $228 \pm 31$ \\
Protein b & $99.2 \pm 10.5$ & $134 \pm 7.4$ & $97.8 \pm 3.8$ & $135 \pm 3.4$ \\
Collagen b & $10.9 \pm 1.14$ & $15.5 \pm 2.6$ & $12.5 \pm 1.4$ & $14.9 \pm 1.6$ \\
Hexosamine b & $1.16 \pm 0.52$ & $1.98 \pm 0.23$ & $1.41 \pm 0.41$ & $2.18 \pm 0.17$ \\
Phospholipid phosphorous $b$ & $0.77 \pm 0.04$ & $0.66 \pm 0.09$ & $0.70 \pm 0.09$ & $0.70 \pm 0.04$ \\
Total cholesterol b & $7.25 \pm 0.93$ & $9.31 \pm 0.12$ & $6.30 \pm 0.11$ & $7.61 \pm 0.37$ \\
Free cholesterol b & $5.16 \pm 0.72$ & $5.29 \pm 0.18$ & $5.14 \pm 1.0$ & $4.66 \pm 0.37$ \\
\hline
\end{tabular}

a Expressed in grams

b Expressed in milligrams per gram of fresh weight of lungs. 
Table 3. The mean \pm the standard deviation of six determinations of enzymatic changes in the lungs of the asbestotic and control rats.

\begin{tabular}{lcccc}
\hline Enzymes a & Control & Amosite & Anthophyllite & Chrysotile \\
\hline Aldolase & $58.9 \pm 11.1$ & $56.8 \pm 11.4$ & $42.8 \pm 8.56$ & $55.8 \pm 11.2$ \\
Hexokinase & $177 \pm 20$ & $103 \pm 35$ & $142 \pm 46$ & $201 \pm 37$ \\
Lactic dehydrogenase & $5.50 \pm 0.57$ & $8.00 \pm 1.44$ & $8.70 \pm 1.03$ & $10.4 \pm 1.68$ \\
Acid phosphatase & $2.70 \pm 0.41$ & $5.77 \pm 0.32$ & $2.41 \pm 0.19$ & $4.96 \pm 0.51$ \\
Alkaline phosphatase & $10.7 \pm 0.85$ & $10.4 \pm 2.90$ & $9.75 \pm 0.64$ & $9.02 \pm 2.70$ \\
Glutamic oxaloacetate transaminase & $4.50 \pm 0.59$ & $5.0 \pm 0.81$ & $3.12 \pm 0.74$ & $4.00 \pm 0.36$ \\
Glutamic pyruvate transaminase & $1.46 \pm 0.85$ & $1.50 \pm 0.20$ & $2.26 \pm 0.20$ & $2.93 \pm 0.58$ \\
\hline
\end{tabular}

a Aldolase activity is expressed as $\mu$ moles of fructose 1,6 -diphosphate transformed, hexokinase as ", moles acid labile phosphate decreased, lactic dehydrogenase as " moles of reduced nicotinamide adenine dinucleotide oxidized, acid and alkaline phosphatase as milligrams of phenol liberated, and transaminases as moles pyruvate formed per gram of fresh tissue under the respective assay conditions.

Chrysotile. The weight of the lung tissue of the animals treated with chrysotile was 1.7-fold higher than that of the controls. Dry solid content also registered an increase of $25 \%$. There was a $35 \%$ increase in protein content $(\mathrm{p}<0.1 \%)$. Col lagen content in milligrams per gram of fresh weight showed a $37 \%$ increase. The intensity of collagen deposition became more apparent (2.6-fold increase) when the values were expressed per lung.

Hexosamine content showed an $88 \%$ increase due to chrysotile, when expressed in terms of fresh weight $(p<0.1 \%)$. Phospholipids, total cholesterol, and free cholesterol did not show any statistically significant change.

\section{Enzyme activities}

The activities of the various enzymes in the four groups of animals are recorded in table 3 .

Amosite. Fructose diphosphate aldolase activity did not show any change due to this dust. Lactic dehydrogenase and acid phosphatase activities were increased by 46 and $114 \%$, respectively $(\mathrm{p}<0.1 \%)$. Hexolxinase activity tended to decrease by $42 \%(p<1 \%)$. Alkaline phosphatase, glutamic pyruvate transaminase, and glutamic oxaloacetate transaminase were unaffected by amosite.

Anthophyllite. The only significant change was a $58 \%$ increase in lactic dehydrogenase $(\mathrm{p}<0.1 \%)$.
Chrysotile. The activities of hexolkinase, aldolase, glutamic oxaloacetate transaminase, and alkaline phosphatase showed no change. Lactic dehydrogenase and acid phosphatase increased by 69 and $84 \%$ $(\mathrm{p}<0.1 \%)$, and glutamic pyruvate transaminase by $100 \%(\mathrm{p}<1 \%)$.

\section{DISCUSSION}

The present results permit an understanding of some of the chemical changes produced by asbestos in lungs, and they may be helpful therefore in understanding the biochemical basis of toxicity. Anthophyl lite did not produce any apparent chemical changes in the present experiment, whereas the other two forms of asbestos caused significant alterations. This result is in agreement with the observation of differences in chemical composition, solum bility, and effect on mitochondrial enzymes $(2,8,9)$ of this dust as compared to the other two.

The increase in dry solid content in the asbestotic lung indicated that relative water content varied between the control and experimental animals. Therefore, it was not considered as a suitable param meter for expressing the contents of various constituents for comparative purposes. In terms of fresh weight collagen and hexosamine contents were found to accumulate in the lungs of animals treated with amosite and chrysotile. This finding agrees with the observation of reticulin type fibrosis in animals treated with amo- 
site (13). In addition to collagen noncollagen protein (total protein-collagen) also tended to increase. This result may be indicative of the role of extrapulmonary proteins in the process of asbestos body formation (3).

The increase in lactic dehydrogenase, exhibited by all the three dusts, may be indicative of a metabolic adaptation to anaerobic conditions as reported for silicosis (6) and may also be related to the role of macrophages in foreign body reaction. The changes in hexokinase, aldolase, alkaline phosphatase, glutamic oxaloacetate transaminase, and glutamic pyruvate transaminase were not significant enough to suggest metabolic alterations. Another interesting feature of the findings is that asbestos dusts which inhibited transaminases and phosphatase activities of lung homogenate in vitro (9) showed a different effect in vivo. It may be pointed out that unlike the enzymes in the soluble fraction, membrane-bound en zymes of the mitochondria and lysosomes seem to be the more likely targets of asbestos toxicity in vivo $(2,14)$. Moreover, the increase in acid phosphatase observed in the case of animals treated with chrysotile and amosite is in agreement with the results on lysosomal enzymes (14).

\section{ACKNOWLEDGMENTS}

Thanks are due to Mr. M. M. Lal for supplying the dusts and Mr. S. D. Pandey for his technical assistance.

\section{REFERENCES}

1. ASHWELL, G, Colorimetric analysis of sugars. In: S. P. COLOWICK and $N$. $O$ KAPLAN (eds), Methods in enzymology (vol, 3). Academic Press, New York, N.Y. 1957, pp. 73-105.

2. BEG, M. U., RAHMAN, Q., VISWANATHAN, P. N. and ZAIDI, S. H. The effect of asbestos dust on mitochondrial enzymes of rat lung. Environ. physiol. \& biochem. 3 (1973) 185-191.

3. BLOUNT, M., HOLT, P. F, and LEACH, A. The protein coating of asbestos bodies. Biochem. j. 101 (1966) 204-207.

4. CRANE, R. K. and SOLS, A. Animal tissue hexokinases. In: S. P. COLOWICK and N. O. KAPLAN (eds.), Methods in enzymology (vol. 1). Academic Press, New York, N.Y. 1955, pp. 277-286.

5. KORNBERG, A. Lactic dehydrogenases of muscle. In: S.P. Colowick and N. O. KAPLAN (eds.), Methods in enzymology (vol. 1). Academic Press, New York, N.Y. 1955, pp. $441-443$

6. LINDY, S., KAHANPÄA, K., KARHU NEN, P., HALIME, $J$, and UITTO, J LACtate dehydrogenase isoenzymes during the development of experimental fibrosis. J. lab. clin. med. 76 (1970) $756-760$.

7. LOWRY, O. H., ROSEBROUGH, N. J., FARR, A. L. and RANDALL, R.J. Protein measurement with Folin phenol reagent. J. biol. chem. 193 (1951) 265-275.

8. RAHMAN, Q., VISWANATHAN, P. N. and TANDON, S. K. In vitro dissolution of three varieties of asbestos in physiological fluids. Work-environ.-health 11 (1974) 3942.

9. RAHMAN, Q., BEG, M. U. VISWANATHAN, P. N. and ZAIDI, S. H. Relation between solubility of silicates and enzyme inhibition in lung homogenates (in vitro studies). Environ, physiol. \& biochem. 3 (1973) $281-285$.

10. SCHNEIDER, W. C. Methods for the isolation of particulate components of the cell. In: W. W. UMBREIT, R. H. BURRIS and J. F. STAUTFER (eds.), Monometric techniques. Burgess Publishing Co., Minneapolis, Minn. 1968, pp. $177-192$

11. SIBLEY, J. A. and LEHNINGER, A. L. Determination of aldolase in animal tissues. J. biol. chem. 177 (1949) $859-872$.

12. STEGEMANN, H. Micro determination of hydroxyproline with chloromine- $\mathrm{T}$ and $\mathrm{P}$. dimethyl aminobenzaldehyde. Hoppe Seylers Z. physiol. Chem. 311 (1958) $41-45$.

13. VISWANATHAN, P. N., DOGRA, R. K. S., SHANKER, R. and ZAIDI, S. H. Pulmonary fibrogenic response of guineapigs to amosite dust. Int. Arch. Arbeitsmed. 31 (1973) $51-59$.

14. VISWANATHAN, P. N., RAHMAN, Q., BEG, M. U. and ZAIDI, S. H. Pulmonary lysosomal enzymes in experimental asbesm tosis in guineapigs. Environ. physiol. \& biochem. 3 (1973) $120-126$.

15. VISWANATHAN, P. N., ANAND, M RAFIMAN, Q., BEG., M. U. and ZAIDI, $S$. H. Biochemical changes in serum of guineapigs in experimental asbestosis. Chemosphere 3 (1973) 119-124.

16. WOOTTON, I. D. P. Micro analysis in medical biochemistry. J. and A. Churchill Ltd., London 1964, pp. 83-86, 101-105, $112-114$

17. ZAXDI, S. H. Experimental methods. In: Experimental pneumoconiosis. Johns Hopkins Press, Baltimore, Md. 1969, pp. 35-49.

18. ZAIDI, S. H. and KAW, J. D. Jeffect of dietary deficiency and protein malnutrition on the fibrogenesis caused by silica dusts in rats. $B r . j$. ind. med. 27 (1970) 250-259.

Received for publication: $1974-06-12$ 